\title{
Noble gas isotopes and mineral chemistry recording partial melting and subduction-related metasomatism in spinel-lherzolites from Coyhaique, Chilean Patagonia
}

\author{
E. NOVAIS-RODRIGUES ${ }^{1}$, T. JALOWITZKI ${ }^{1}$, F. \\ GERVASONI $^{2}, \mathrm{H}$. SUMINO ${ }^{3}$, Y. BUSSWEILER ${ }^{4}$, J. \\ BERNDT $^{4}$, S. KLEMME ${ }^{4}$, L. TELES ${ }^{1}$, R. V. CONCEIÇÃO ${ }^{5}$, \\ M. E. SCHILLING ${ }^{6}$, G. W. BERTOTTO ${ }^{7}$ \\ ${ }^{1}$ Universidade de Brasília, Brazil (enrmesmo@gmail.com). \\ ${ }^{2}$ Universidade Federal de Goiás, Brazil. \\ ${ }^{3}$ University of Tokyo, Japan. \\ ${ }^{4}$ University of Münster, Germany. \\ ${ }^{5}$ Universidade Federal do Rio Grande do Sul, Brazil. \\ ${ }^{6}$ Universidad Austral de Chile, Chile. \\ ${ }^{7}$ CONICET-Universidad Nacional de La Pampa, Argentina
}

Noble gas isotopes are important geodynamic tracers to elucidate Earth's mantle processes, given their large variations in abundance and isotopic compositions in different geochemical reservoirs. The xenoliths studied here are classified as spinel-lherzolite and were collected from the Balmaceda flood basalts (54-59 Ma), $320 \mathrm{~km}$ from the Chile Trench. Major and trace elements from olivine (ol), orthopyroxene (opx), clinopyroxene (cpx), and spinel (sp) of sixteen lherzolites were determined by EPMA and LA-ICPMS. Noble gas isotopes ( $\mathrm{He}, \mathrm{Ne}, \mathrm{Ar})$ of five selected lherzolites were determined by the crushing extraction method (100, 500, 1000 and 2000 strokes for each sample). Negative correlations of $\mathrm{Al}_{2} \mathrm{O}_{3}$ content with $\mathrm{Mg} \#$ in cpx and opx, and with $\mathrm{Cr} \#$ of spinel indicate a residual character. Cpx-opx geothermometry indicates equilibrium temperatures between 939 and $1132{ }^{\circ} \mathrm{C}$. Cpx shows positive anomalies of $\mathrm{Li}$ and negative high field strength element anomalies in primitive mantle normalized multielement diagrams. We conclude that there are two types of cpx: a LREE-depleted cpx (partial melting) and LREE-enriched cpx (metasomatism). The ol and opx trace element compositions record mantle depletion. Here we report the first strongly radiogenic ${ }^{3} \mathrm{He} /{ }^{4} \mathrm{He}$ ratios for mantle xenoliths from Patagonia $\left(0.20-2.52 \mathrm{R}_{\mathrm{A}}\right)$, attesting volatile recycling via subduction. The neon isotope ratios are nucleogenic considering samples distinct from air within $1 \sigma$ uncertainty $\left({ }^{21} \mathrm{Ne} /{ }^{22} \mathrm{Ne}=0.0299-0.0308\right)$. The ${ }^{40} \mathrm{Ar} /{ }^{36} \mathrm{Ar}$ ratios range from 325 to 551, indicating atmospheric contamination. Therefore, the subcontinental lithospheric mantle beneath Coyhaique records both partial melting processes and the contribution of a slab-derived components. 